\title{
Peripheral mechanisms contributing to the glucocorticoid hypersensitivity in proopiomelanocortin null mice treated with corticosterone
}

\author{
Zoi Michailidou, Anthony P Coll ${ }^{1}$, Christopher J Kenyon, Nicholas M Morton, Stephen O'Rahilly ${ }^{1}$, \\ Jonathan R Seckl and Karen E Chapman \\ Endocrine Unit, Queen's Medical Research Institute, Centre for Cardiovascular Sciences, University of Edinburgh, 47 Little France Crescent, Edinburgh \\ EH16 4TJ, UK \\ ${ }^{1}$ Departments of Clinical Biochemistry and Medicine, Cambridge Institute for Medical Research, Addenbrooke's Hospital, Cambridge CB2 2XY, UK \\ (Requests for offprints should be addressed to K E Chapman; Email: karen.chapman@ed.ac.uk)
}

\begin{abstract}
Proopiomelanocortin (POMC) deficiency causes severe obesity through hyperphagia of hypothalamic origin. However, low glucocorticoid levels caused by adrenal insufficiency mitigate against insulin resistance, hyperphagia and fat accretion in $\mathrm{Pomc}^{-1-}$ mice. Upon exogenous glucocorticoid replacement, corticosterone-supplemented (CORT) Pomc ${ }^{-1-}$ mice show exaggerated responses, including excessive fat accumulation, hyperleptinaemia and insulin resistance. To investigate the peripheral mechanisms underlying this glucocorticoid hypersensitivity, we examined the expression levels of key determinants and targets of glucocorticoid action in adipose tissue and liver. Despite lower basal expression of $11 \beta$ hydroxysteroid dehydrogenase type 1 (11ß-HSD1), which generates active glucocorticoids within cells, CORT-mediated induction of $11 \beta-\mathrm{HSD} 1 \mathrm{mRNA}$ levels was more pronounced
\end{abstract}

in adipose tissues of Pomc ${ }^{-/-}$mice. Similarly, CORT treatment increased lipoprotein lipase mRNA levels in all fat depots in Pomc $^{-1-}$ mice, consistent with exaggerated fat accumulation. Glucocorticoid receptor (GR) mRNA levels were selectively elevated in liver and retroperitoneal fat of $\mathrm{Pomc}^{-1-}$ mice but were corrected by CORT in the latter depot. In liver, CORT increased phosphoenolpyruvate carboxykinase mRNA levels specifically in Pomc ${ }^{-1-}$ mice, consistent with their insulinresistant phenotype. Furthermore, CORT induced hypertension in $\mathrm{Pomc}^{-1-}$ mice, independently of adipose or liver reninangiotensin system activation. These data suggest that CORTinducible $11 \beta-H S D 1$ expression in fat contributes to the adverse cardiometabolic effects of CORT in POMC deficiency, whereas higher GR levels may be more important in liver. Journal of Endocrinology (2007) 194, 161-170

\section{Introduction}

Glucocorticoids exert pleiotrophic effects on metabolism and energy partitioning. Centrally, they increase food intake and reduce energy expenditure, whilst peripherally, they promote insulin resistance, fat accumulation (Dallman et al. 1993, Kellendonk et al. 2002) and hypertension (Saruta 1996, Whitworth et al. 2001). Polymorphisms in the human glucocorticoid receptor NR3c1 gene (GR) are associated with glucocorticoid hypersensitivity, visceral obesity, hypertension and increased cardiovascular disease risk (Buemann et al. 1997, Rosmond et al. 2000, Dobson et al. 2001, Ukkola et al. 2001a,b, van Rossum et al. 2003). Many rodent models of obesity are characterised by hypercorticosteronaemia, with weight gain normalised following adrenalectomy and reinstated by glucocorticoid replacement (Debons et al.1982, Freedman et al. 1986, Sainsbury et al.1997, Makimura et al. 2000). Although plasma glucocorticoid levels are normal in human idiopathic obesity (Flier 2004), it has been proposed that intra-adipose glucocorticoid action is selectively increased, through increased adipose expression of $11 \beta$-hydroxysteroid dehydrogenase type 1 (11ß-HSD1), the intracellular enzyme that regenerates active glucocorticoids from intrinsically inert 11-keto-glucocorticoids (Kotelevtsev et al. 1997, Jamieson et al. 2000, Andrew et al. 2002).

Obese humans (Rask et al. 2001, Paulmyer-Lacroix et al. 2002, Lindsay et al. 2003, Kannisto et al. 2004) and some rodent models of obesity (Livingstone et al. 2000, Masuzaki et al. 2001) have selectively increased adipose levels of $11 \beta$ HSD1 and transgenic overexpression of $11 \beta-H S D 1$ in adipocytes causes hyperphagia, obesity, insulin resistance and hypertension despite unchanged systemic glucocorticoid levels (Masuzaki et al. 2001, 2003). Hepatic overexpression of $11 \beta-H S D 1$ has no effect on adiposity, but causes hypertension and insulin resistance (Paterson et al. 2004). Conversely, mice deficient in 11ß-HSD1 are insulin sensitised and resist the adverse metabolic effects of a high-fat diet (Kotelevtsev et al. 1997, Morton et al. 2001, 2004). 
Proopiomelanocortin (POMC) is a polypeptide precursor which undergoes extensive post-translational modification to yield a range of smaller, biological active peptides. These include $\alpha-, \beta$ - and $\gamma$-melanocyte-stimulating hormone and adrenocorticotrophic hormone (ACTH), collectively known as melanocortins. Inactivating mutations of the $P O M C$ gene in humans and mice result in a complex phenotype. Loss of melanocortin signalling within the hypothalamus causes hyperphagia and obesity (Krude et al. 1998, Yaswen et al.1999, Challis et al. 2004). Further, a failure to produce ACTH within the anterior pituitary causes adrenal insufficiency with low or absent circulating glucocorticoids (Krude et al. 1998, Yaswen et al.1999, Challis et al. 2004). Pomc ${ }^{-/-}$mice are therefore unusual amongst rodent models in that obesity develops in the absence of circulating glucocorticoids. However, glucocorticoid treatment exacerbates hyperphagia and obesity in adult $\mathrm{Pomc}^{-1-}$ mice and induces severe insulin resistance, hyperleptinaemia and diabetes (Coll et al. 2005).

We have tested the hypothesis that increased glucocorticoid action in peripheral tissues of glucocorticoid-treated $\mathrm{Pomc}^{-1-}$ mice contributes to their apparent glucocorticoid hypersensitivity and exaggerated metabolic syndrome-like phenotype. We further demonstrate that glucocorticoid replacement induces hypertension in $\mathrm{Pomc}^{-/-}$mice, independently of reninangiotensin system (RAS) activation.

\section{Materials and Methods}

\section{Animals and CORT replacement}

The generation of $\mathrm{Pomc}^{-1-}$ mice on a $129 / \mathrm{SvEv}$ background has been described previously (Challis et al. 2004). All mice were housed in standard conditions on a $12 \mathrm{~h}$ light: $12 \mathrm{~h}$ darkness cycle (lights on $0070 \mathrm{~h}$ ) with ad libitum access to water and chow (4.5\% fat diet, Special Diet Services, Witham, UK). Eight-week-old male mice ( $n=5$ per group) were treated with corticosterone $(25 \mu \mathrm{g} / \mathrm{ml})$ in their drinking water, a dose that results in similar plasma glucocorticoid levels and hypothalamic corticotrophin releasing hormone (CRH) mRNA levels in Pomc ${ }^{-1-}$ and wildtype mice (Coll et al. 2005). All animal protocols used in these studies were approved under the auspices of the UK Home Office Animals (Scientific Procedures) Act 1986.

\section{Blood pressure measurement}

Systolic blood pressure was measured photoelectrically in the tail of restrained conscious mice using an IITC model 179 analyser (Woodland Hills, CA, USA). Prior to recording measurements, all mice underwent three periods of training to accustom them to the procedure. Mice were warmed at $32{ }^{\circ} \mathrm{C}$ for $30 \mathrm{~min}$ before taking ten consecutive readings. The first five were discounted and a mean value of systolic blood pressure was calculated from the last five readings. Five mice from each treatment group were measured. All analogue recordings were analysed by an independent observer who was blinded to the genotype of the mice and any treatment they had received.

\section{Plasma hormone and lipid measurements}

Animals were killed between 0800 and $0900 \mathrm{~h}$ by cervical dislocation. Trunk blood samples were collected into EDTAcoated tubes (Sarstedt, Leicester, UK), centrifuged at $6000 \boldsymbol{g}$ for $10 \mathrm{~min}$ and plasma stored at $-80{ }^{\circ} \mathrm{C}$ until required for assay. Non-esterified fatty acid (NEFA) and triglyceride levels were determined by commercial kits (NEFA, Roche Diagnostics; triglyceride, Dade Behring, Marburg, Germany). Plasma renin and angiotensinogen concentrations were determined as previously described (Morton et al. 2005).

\section{Tissue morphology and hepatic triglyceride levels}

Neutral lipids, cholesterol and fatty acids were identified by light microscopy at $40 \times$ magnification in cryostat liver sections $(30 \mu \mathrm{m})$ stained with oil red $\mathrm{O}$ (Sigma) and counter stained with haematoxylin as previously described (Morton et al. 2005). Hepatic triglycerides were extracted by homogenisation in isopropanol (ten volumes) and then incubated at $37^{\circ} \mathrm{C}$ for $45 \mathrm{~min}$ and measured spectrophotometrically in supernatants (3000 $\boldsymbol{g}$ for $10 \mathrm{~min}$ ) using reagent TR224221 (Alpha Laboratories, Eastleigh, Hampshire, UK).

\section{RNA extraction and northern blot analysis}

Pieces of liver and adipose tissues (inguinal, retroperitoneal and epididymal) were rapidly frozen in dry ice, stored at $-80{ }^{\circ} \mathrm{C}$ and then homogenised in Trizol reagent (Invitrogen). Total RNA was purified using a binding matrix (RNaid Plus kit, BIO 101; Anachem, UK) and eluted in diethylpyrocarbonate-treated water containing $400 \mathrm{U} / \mathrm{ml} \mathrm{RNasin} \mathrm{(Promega)} \mathrm{and} 10 \mathrm{mmol} / 1$ dithiothreitol. RNA $(5-10 \mu \mathrm{g})$ was blotted and hybridised to ${ }^{32}$ P-labelled cDNA probes for mouse $11 \beta-H S D 1$, GR, angiotensinogen, phosphoenolpyruvate carboxykinase (PEPCK), lipoprotein lipase (LPL) and $18 \mathrm{~S}$ as previously described (Morton et al. 2005). Specific mRNAs were quantified using a phosphorimager (Fuji BAS FLA 2000, Raytek, Sheffield,

\footnotetext{
Figure 1 Mediators of GC action in adipose tissue of $\mathrm{Pomc}^{-1-}$ mice and effects of CORT treatment on GC target genes. (A) Representative northern blot showing levels of $11 \beta$-HSD1 mRNA and 18 S RNA in epididymal adipose tissue of Pomc ${ }^{-/-}(-/-)$and wild-type $(+/+)$ mice, either untreated or treated for 10 days with corticosterone (cort). (B-E) Quantitation of adipose tissue-specific $11 \beta$-HSD1 (B), GR (C), LPL (D) and PEPCK (E) mRNA levels in experimental mice. Epi, epididymal fat; ing, inguinal fat; retro, retroperitoneal fat. Data are presented as percentage of the value in untreated wild-type mice $(100 \%)$ and are the means \pm S.E.M.; $n=5$ per group. Significance $* P<$ $0 \cdot 05, * * P<0 \cdot 01$ and $* * * P<0 \cdot 001$.
} 
A

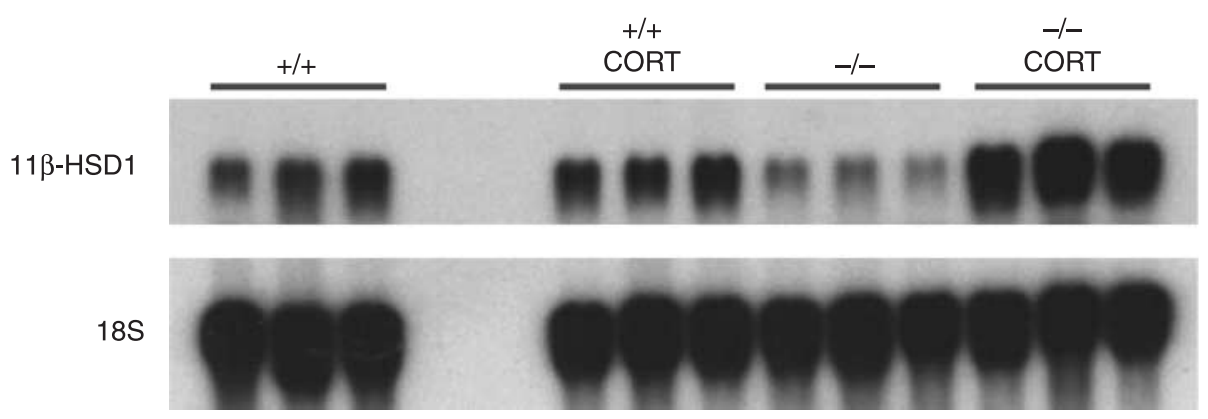

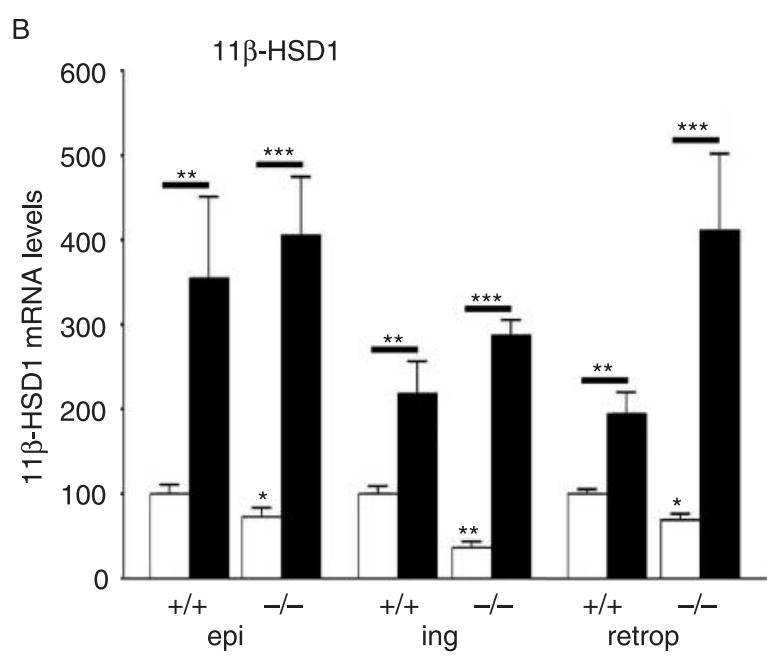

D

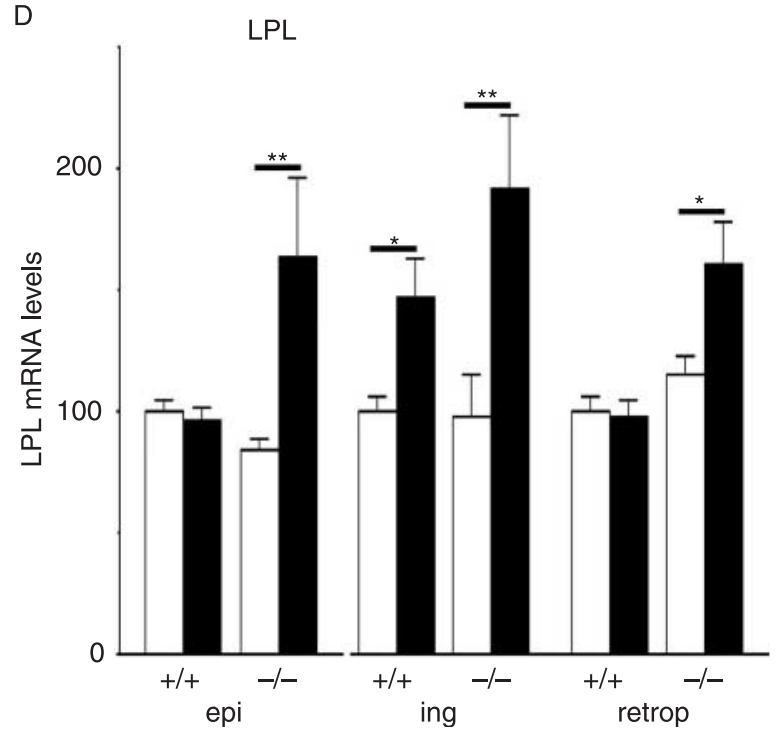

www.endocrinology-journals.org
C

GR

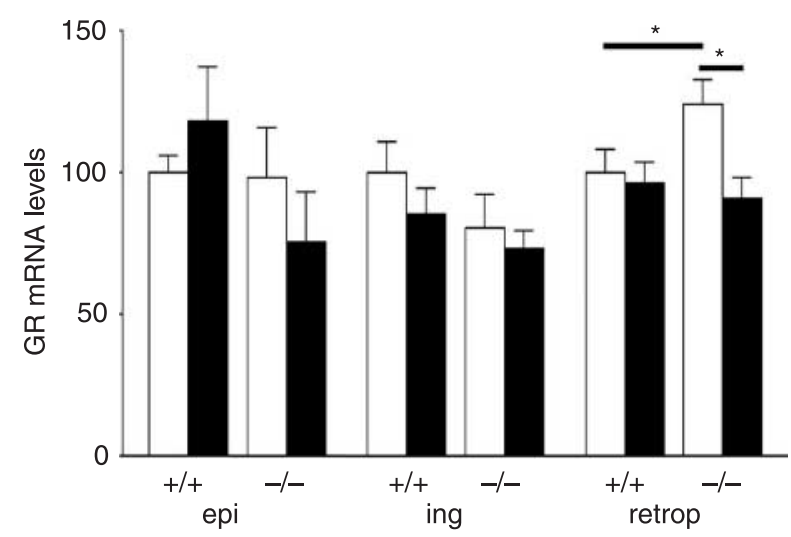

E PEPCK

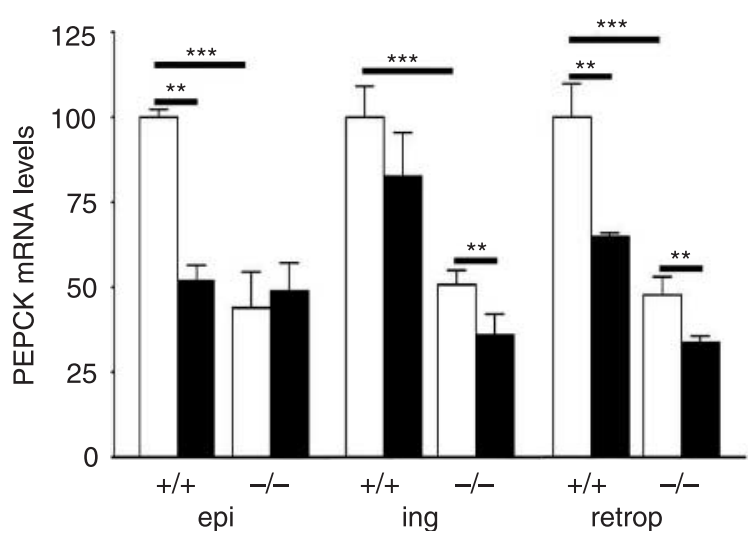

Journal of Endocrinology (2007) 194, 161-170 
UK) and Aida image analysis software (Raytek) and are expressed in arbitrary units relative to $18 \mathrm{~S}$ RNA.

\section{Statistical analyses}

The effects of genotype and corticosterone interactions were assessed by two-way ANOVA followed by post hoc Tukey's tests for group differences. Significance was set at $P<0 \cdot 05$. Values are means \pm s.E.M.

\section{Results}

Pomc $^{-1-}$ mice have reduced intra-adipose GC action but exaggerated CORT-mediated GC amplification

Corticosterone-treated $\mathrm{Pomc}^{-1-}$ and wild-type mice had similar plasma corticosterone levels and hypothalamic $\mathrm{CRH}$ mRNA levels (Coll et al. 2005). To examine potential mechanisms of corticosterone hypersensitivity in $\mathrm{Pomc}^{-1-}$ mice, $11 \beta-H S D 1$ and GR mRNA levels were measured in epididymal, inguinal and retroperitoneal adipose depots. Adipose $11 \beta$-HSD1 mRNA expression was lower in all untreated $\mathrm{Pomc}^{-1-}$ compared with wild-type mice (Fig. 1A) and was dramatically increased by corticosterone in both genotypes (Fig. 1A), with larger increases (two- to four-fold greater) in $\mathrm{Pomc}^{-1-}$ mice.

Adipose expression of GR mRNA was higher in the retroperitoneal fat of $\mathrm{Pomc}^{-1-}$ mice and restored to wildtype levels by corticosterone treatment (Fig. 1B). GR mRNA levels did not differ in inguinal and epididymal fat between $\mathrm{Pomc}^{-1-}$ and wild-type mice, and were unaffected by corticosterone treatment in either genotype (Fig. 1B).

To investigate mechanisms downstream of $11 \beta-H S D 1 / G R$ by which corticosterone treatment selectively increases fat mass in $\mathrm{Pomc}^{-1-}$ mice, adipose levels of mRNA encoding LPL, a glucocorticoid-regulated gene (Fried et al. 1993), were measured. Although LPL mRNA levels were the same in untreated $\mathrm{Pomc}^{-1-}$ and wild-type mice in all depots, adipose LPL expression in $\mathrm{Pomc}^{-1-}$ mice was markedly increased by corticosterone treatment (Fig. 1C) consistent with increased triglyceride uptake, and fat mass in Pomc ${ }^{-/-}$mice. In wild-type mice, corticosterone treatment increased LPL mRNA only in the inguinal depot, and to a lesser extent than in $\mathrm{Pomc}^{-/-}$mice (Fig. 1C), suggesting adipose depot-dependent regulation of LPL by glucocorticoids in non-obese mice, consistent with previous data in rats (Freedman et al. 1986).

PEPCK is an enzyme essential for gluconeogenesis in liver and glycerol synthesis in adipose tissue (Pilkis \& Granner 1992, Reshef et al. 2003). PEPCK is a classical glucocorticoid target gene which is positively regulated by glucocorticoids in hepatocytes and negatively regulated in adipocytes (Sasaki et al.1984, Nechushtan et al. 1987). Consistent with this, adipose PEPCK mRNA levels were decreased in epididymal and retroperitoneal fat by corticosterone treatment in wildtype mice (Fig. 1D). Surprisingly, given their glucocorticoid deficiency, Pomc ${ }^{-1-}$ mice had lower levels of PEPCK mRNA in adipose tissue than in wild-type (Fig. 1D). However, although corticosterone treatment in $\mathrm{Pomc}^{-1-}$ mice decreased PEPCK expression in inguinal and retroperitoneal adipose tissue (significantly lower than in corticosterone-treated wild-type mice; $P=0 \cdot 01$ ), it had no effect on PEPCK mRNA levels in epididymal adipose tissue, suggesting that other regulatory factors dominate PEPCK expression in adipose tissue of $\mathrm{Pomc}^{-1-}$ mice (Fig. 1D).

Pomc $^{-1-}$ mice are dyslipidaemic, and have unaltered hepatic 11ß-HSD1 but higher GR mRNA levels

Hepatic $11 \beta-H S D 1$ mRNA levels were similar between the two genotypes (Fig. 2A) and unaffected by corticosterone (Fig. 2A). Hepatic GR mRNA levels were higher in Pomc ${ }^{-1-}$ compared with wild-type mice (Fig. 2B), but again corticosterone had no effect on GR mRNA levels (Fig. 2B).

Hepatic PEPCK expression was lower in Pomc ${ }^{-1-}$ than in wild-type mice (Fig. 2C) and was increased by corticosterone treatment to levels equivalent to untreated wild-type mice. In contrast, corticosterone decreased hepatic PEPCK mRNA levels in wild-type mice (Fig. 2C).

Pomc $^{-1-}$ mice showed markedly higher circulating triglyceride levels (Fig. 3A) and hepatic lipid accumulation than wildtype mice (Fig. 3B), with sixfold higher levels of hepatic triglyceride $(P<0 \cdot 001 ;$ Fig. 3C). However, corticosterone had no effect on plasma triglyceride levels in either genotype (Fig. 3A), nor did it worsen the liver phenotype (Fig. 3C). Pomc $^{-1-}$ and wild-type mice had similar plasma NEFA levels which were unaffected by corticosterone (Fig. 3D).

CORT drives hypertension in Pomc ${ }^{-1-}$ mice independently of adipose and liver $R A S$ activation

Pomc $^{-1-}$ mice had similar blood pressure to wild-type mice (Fig. 4A). Corticosterone markedly increased blood pressure only in $\mathrm{Pomc}^{-1-}$ mice (Fig. 4A). Since hypertension following transgenic expression of $11 \beta-H S D 1$ in adipose or liver is associated with increased levels of angiotensinogen in each of these tissues respectively (Masuzaki et al. 2001, Paterson et al. 2004), we hypothesised that a similar mechanism may drive corticosterone-mediated hypertension in Pomc ${ }^{-1-}$ mice. We therefore examined key components of the RAS (Guyton 1991). Pomc ${ }^{-1-}$ mice had higher hepatic angiotensinogen mRNA levels than controls (Fig. 4B). However, corticosterone did not alter hepatic angiotensinogen mRNA levels in either genotype (Fig. 4B). Consistent with lower intra-adipose $\mathrm{GC}$ action, adipose angiotensinogen mRNA levels were lower in Pomc ${ }^{-1-}$ mice in all adipose depots (Fig. 4C). Corticosterone increased angiotensinogen mRNA levels specifically in epididymal adipose tissue of both genotypes (twofold increase; $P<0 \cdot 001$; Fig. $4 \mathrm{C}$ ) but had no effect on angiotensinogen mRNA levels in inguinal or retroperitoneal adipose tissue of either genotype (Fig. 4C). Plasma angiotensinogen 
A
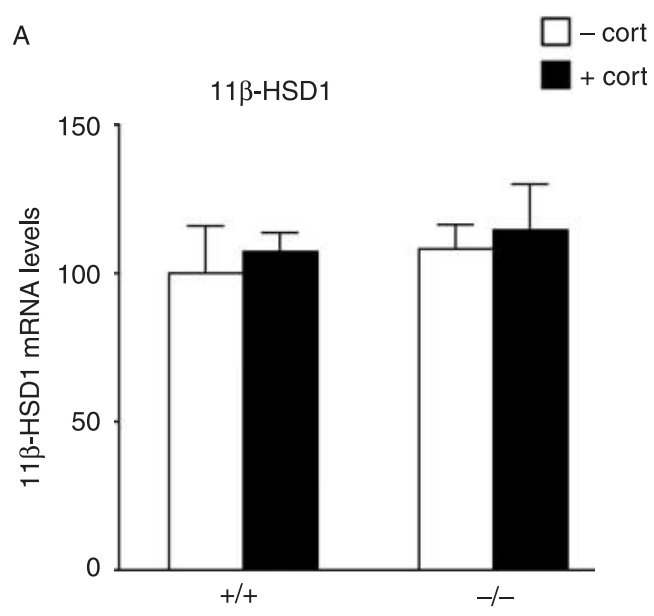

B

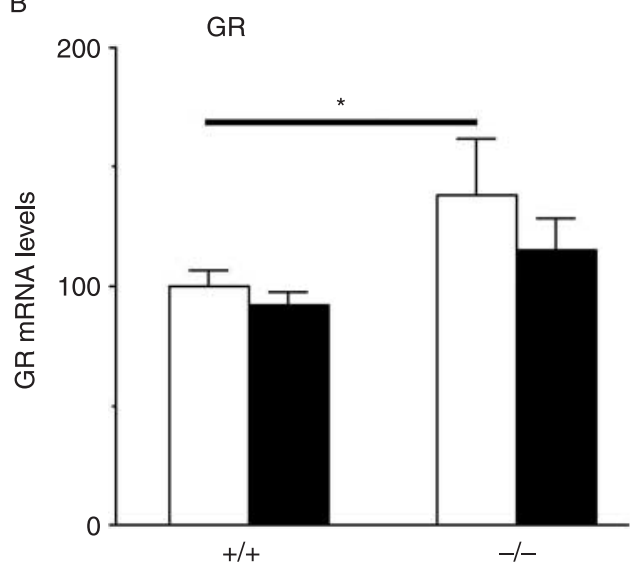

C

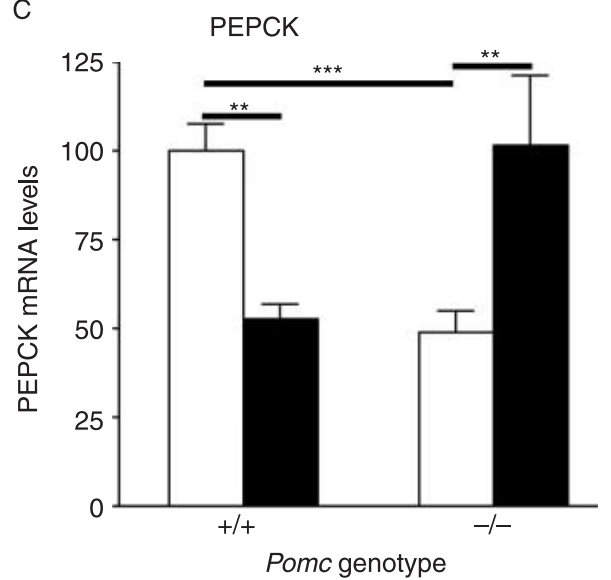

Figure 2 Mediators of GC action in the liver of $\mathrm{PomC}^{-/-}$mice and effects of CORT treatment on GC target genes. Liver mRNA expression of (A) $11 \beta-$ HSD1, (B) GR and (C) PEPCK in Pomc ${ }^{-/-}$ $(-/-)$ and wild-type $(+/+)$ mice, either untreated or treated for 10 days with corticosterone (cort). Data are presented as percentages of the value in untreated control mice $(100 \%)$ and are the means \pm S.E.M.; $n=5$ per group. Significance $* P<0 \cdot 05, * * P<$ $0 \cdot 01$ and ${ }^{* * *} P<0 \cdot 001$. concentrations did not differ with genotype or corticosterone (Fig. 4D). As has been found in another model of glucocorticoid-deficient obesity (Morton et al. 2005), plasma renin concentration was markedly higher in $\mathrm{Pomc}^{-1-}$ mice (Fig. 4E) but this was unaffected by corticosterone (Fig. 4E).

\section{Discussion}

Increased glucocorticoid action specifically in adipose (Masuzaki et al. 2001) or liver (Paterson et al. 2004) produces distinct metabolic syndromes with hypertension. Increased GR sensitivity is also associated with altered fat distribution, hypertension and cardiometabolic disease (Buemann et al. 1997, Rosmond et al. 2000, Dobson et al. 2001, Ukkola et al. 2001a,b, van Rossum et al. 2003). We hypothesised that altered tissue regeneration of active glucocorticoid and/or peripheral tissue sensitivity to GCs might explain in part the exaggerated fat accumulation, insulin resistance (Coll et al. 2005) and the hypertension observed in $\mathrm{Pomc}^{-1-}$ mice with glucocorticoid replacement.

With fixed circulating glucocorticoid levels, 11 $\beta$-HSD1 and GR expression levels are the key determinants of GC action. Pomc ${ }^{-1-}$ mice had lower adipose but similar hepatic levels of $11 \beta$-HSD1 mRNA levels to wild-type mice. Corticosterone treatment dramatically and more markedly increased $11 \beta-$ HSD 1 in the adipose tissue of $\mathrm{Pomc}^{-/-}$mice. This was accompanied by a marked increase in the expression of the glucocorticoid-inducible (Fried et al. 1993) gene LPL, which is consistent with the exaggerated accumulation of fat in these mice. Intriguingly, these data suggest that, at least in adipose tissue, $11 \beta-H S D 1$ itself is a glucocorticoid target gene. This finding is consistent with most (Hammami \& Siteri 1991, Jamieson et al. 1995, Voice et al. 1996, Bujalska et al. 1999), but not all (Napolitano et al. 1998) previous reports of glucocorticoid induction of $11 \beta-H S D 1$ in a variety of cell types. Although not specifically measured here, increased adipose $11 \beta$-HSD1 activity is predicted to selectively amplify intra-adipose glucocorticoid concentrations, particularly when circulating levels of substrate are high. On the other hand, our data suggest that congenital glucocorticoid deficiency has little impact upon hepatic $11 \beta$ HSD1 levels in vivo and is not regulated by corticosterone. In contrast, 11 $\beta$-HSD1 mRNA levels are highly and positively regulated by glucocorticoids in adipose tissue.

GR levels are another major determinant of cellular glucocorticoid sensitivity (Vanderbilt et al. 1987, Geley et al. 1996). Small differences in GR mRNA levels can markedly alter glucocorticoid responsiveness (Geley et al. 1996, Reichardt et al. 2000). Pomc $c^{-/-}$mice had elevated GR mRNA levels in liver and retroperitoneal adipose tissue, suggesting increased glucocorticoid sensitivity selectively in these depots. Following corticosterone replacement in $\mathrm{Pomc}^{-/-}$mice, GR mRNA levels were restored to wildtype levels in retroperitoneal adipose tissue but not in liver, consistent with tissue- and time-specific differences in GR 

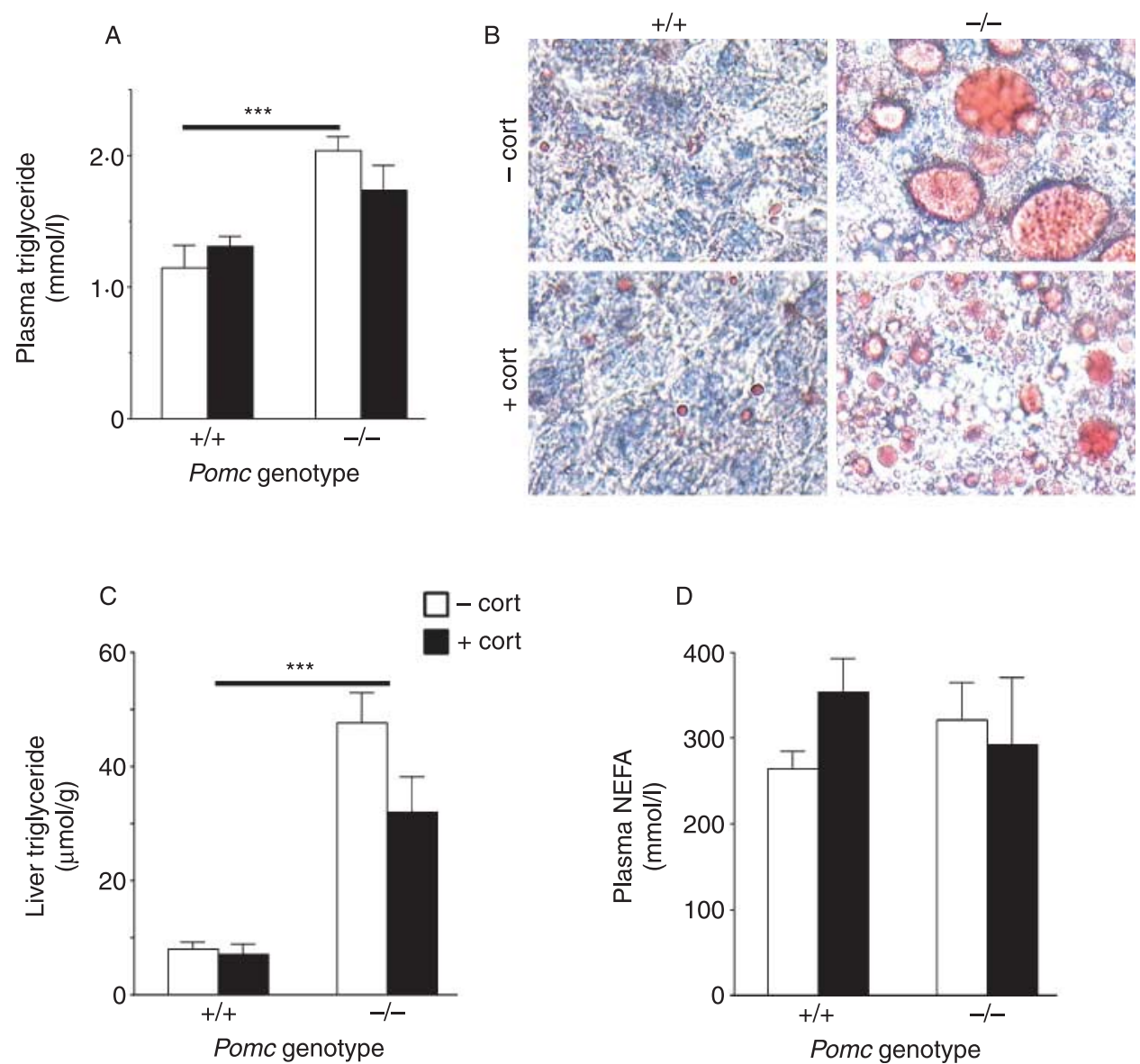

Figure 3 Dyslipidaemia and fatty liver in $\mathrm{Pomc}^{-/-}$mice. (A) Plasma triglyceride levels in Pomc ${ }^{-/-}(-/-)$ and wild-type $(+/+)$ mice, either untreated or treated for 10 days with corticosterone (cort). (B) Oil Red O staining of neutral lipid in liver sections of wild-type mice $(+/+$, left upper panel), CORT-treated wild-type mice $\left(+/+\right.$, left bottom panel), Pomc ${ }^{-/-}\left(-/-\right.$, right upper panel) and CORT-treated Pomc ${ }^{-/-}(-/-$, right bottom panel). Magnification is $40 \times$; red, oil red O; blue, haematoxylin (nuclei). (C) Hepatic triglyceride content in Pomc ${ }^{-/-}(-/-)$and wild-type $(+/+)$mice, either untreated or treated for 10 days with corticosterone (cort). (D) Plasma levels of non-esterified fatty acids (NEFA) in Pomc ${ }^{-1-}(-/-)$ and wild-type $(+/+)$ mice, either untreated or treated for 10 days with corticosterone (cort). Data are means \pm s.E.M.; $(n=6$ per group). Significance $* * * P<0 \cdot 001$.

autoregulation (Kalinyak et al. 1987, Dong et al. 1988, Sheppard et al. 1990, Holmes et al., 1995, 1997, Reichardt et al. 2000).

Corticosterone had no additional effects on the hypertriglyceridaemia and fatty liver of the $\mathrm{Pomc}^{-1-}$ mice, and did not affect plasma NEFAs, which were normal in $\mathrm{Pomc}^{-1-}$ mice. The corticosterone-driven caloric excess in $\mathrm{Pomc}^{-1-}$ mice may drive a further increase in the flux of triglycerides from the liver, that, coupled with increased adipose uptake via LPL, maintains the circulating and liver triglyceride levels constant and is consistent with increased adipose tissue mass in corticosterone-treated Pomc ${ }^{-/-}$mice (Coll et al. 2005).

Adipose PEPCK is critical for glyceroneogenesis and is thus a key regulator of the level of fatty acid re-esterification (reviewed in Reshef et al. 2003). Unexpectedly, since glucocorticoids reduce adipose PEPCK, glucocorticoid- deficient Pomc $^{-1-}$ mice had lower levels of PEPCK mRNA in all adipose depots. This was further decreased by corticosterone treatment. The lower level of PEPCK mRNA in untreated $\mathrm{Pomc}^{-1-}$ mice may be due to their higher fed blood glucose levels (Nechushtan et al. 1987, Opherk et al. 2004), thus reducing the need for glyceroneogenesis to generate glycerol phosphate for fatty acid re-esterification. $\mathrm{Pomc}^{-1-}$ mice have lower hepatic expression of PEPCK. This may not be due to the lack of glucocorticoid signalling in liver, as mice with a liver-specific knockout of GR have normal levels of PEPCK in liver (Opherk et al. 2004), but may be related to the higher circulating levels of insulin in Pomc $^{-1-}$ mice compared with wild-type (Coll et al. 2005). Insulin dominantly and negatively suppresses hepatic PEPCK in the fed state (Pilkis \& Granner 1992). In corticosteronetreated wild-type mice, the repressive effect of insulin 

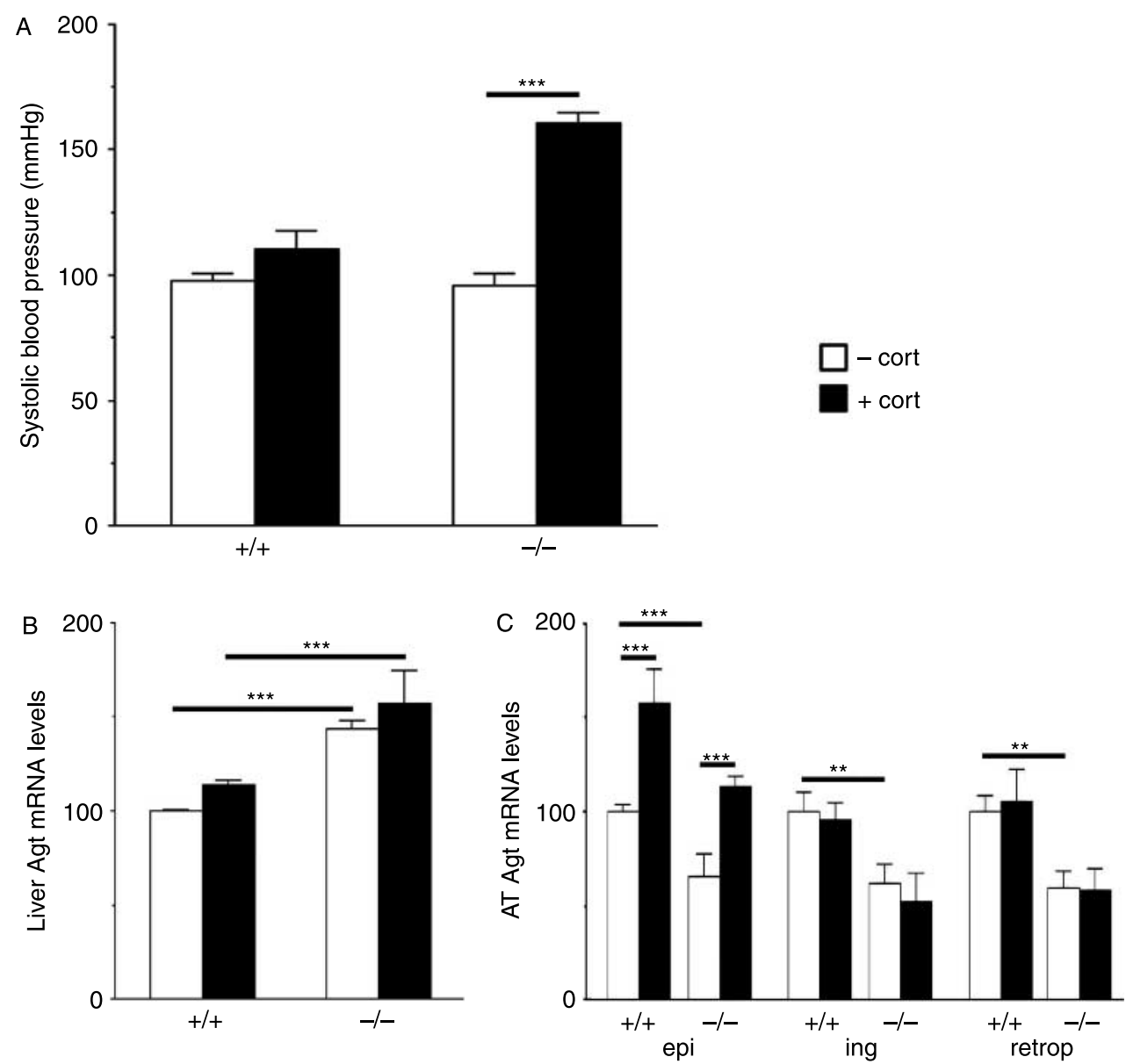

D
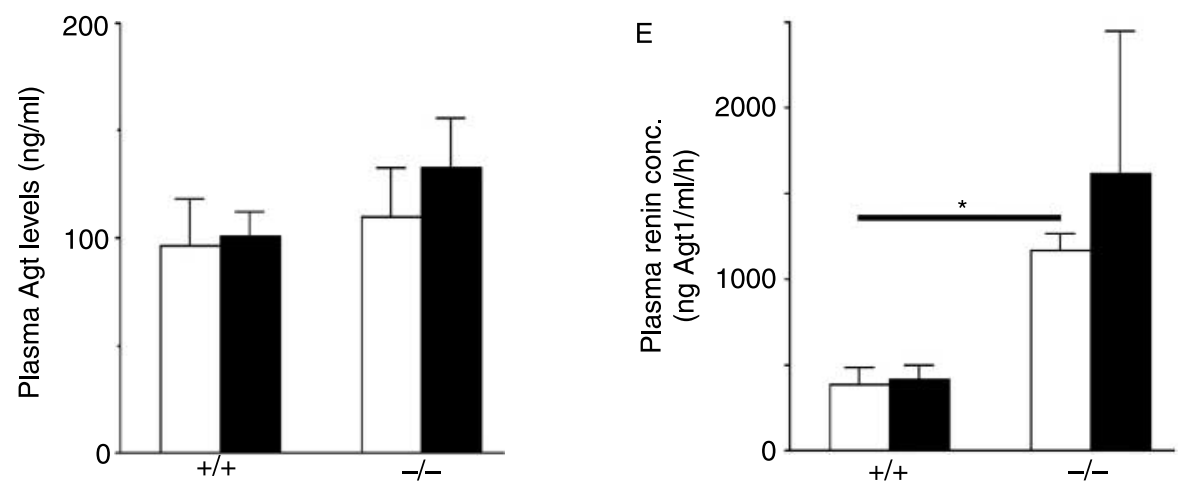

\section{Pomc genotype}

Figure 4 Corticosterone treatment increases blood pressure in Pomc ${ }^{-1-}$ mice: effect of CORT treatment on the Renin-angiotensin system. Effect of 10 days corticosterone treatment (cort) on (A) systolic blood pressure, (B) renin concentration, (C) plasma angiotensinogen, (D) angiotensinogen (Agt) mRNA in adipose tissue (AT), and (E) angiotensinogen (Agt) mRNA levels in liver in wild-type $(+/+)$ and Pomc ${ }^{-/}(-/-)$mice. Epi, epididymal fat; ing, inguinal fat; retro, retroperitoneal fat. Data are means \pm s.E.M., and for transcript levels are expressed relative to levels in untreated wild-type mice $(100 \%) ; n=5$ per group. Significance $* P<0 \cdot 05$, $* * P<0 \cdot 01$ and $* * * P<0 \cdot 001$. 
predominated. Indeed, the decreased levels of PEPCK in these mice compared with untreated wild-type mice may reflect the increase in insulin levels following corticosterone (Coll et al. 2005). In contrast, hepatic PEPCK mRNA levels doubled following corticosterone treatment in $\mathrm{Pomc}^{-/-}$ mice, consistent with hepatic insulin resistance and marked hyperinsulinaemia (Coll et al. 2005).

Blood pressure in $\mathrm{Pomc}^{-/-}$mice is normal despite their hypoadrenal state. This implies that secondary mechanisms are invoked to maintain cardiovascular function when circulating aldosterone and corticosterone concentrations are chronically reduced (Coll et al. 2004). It seems likely that the increased renin activity which we have observed in Pomc $^{-/-}$mice is part of this adaptive process. However, corticosterone replacement did not normalise renin activity and selectively increased blood pressure in $\mathrm{Pomc}^{-1-}$ mice. This was not attributed to a further activation of the circulating RAS, since neither renin nor its substrate angiotensinogen was increased. Indeed, the expression of angiotensinogen mRNA in liver and adipose tissues did not correlate with blood pressure. It seems likely that corticosterone augmented existing mechanisms that were already sustaining vascular function. Apart from renin, these secondary processes are likely to involve the hyperinsulinaemic (Sowers 2004) state of $\mathrm{Pomc}^{-/-}$mice (which is exacerbated by corticosterone treatment; Coll et al. 2005), the sympathetic nervous system (Rascher et al. 1979; which is thought to explain glucocorticoid-induced hypertension in normal mice) or structural adaptation of the vasculature (Wallerath et al. 2004).

In summary, we show that increased adipose tissue-specific sensitivity to glucocorticoids in $\mathrm{Pomc}^{-1-}$ mice may result in part from exaggerated induction of $11 \beta-H S D 1$ in adipose tissue with corticosterone administration. Whilst acknowledging that mRNA changes do not always translate to altered protein (or enzyme activity) levels, these data nevertheless suggest that $11 \beta$-HSD1 might be a more potent mediator of intra-adipose GC action than the GR levels, whereas in liver, higher GR levels contribute to the diabetogenic phenotype of the Pomc ${ }^{-1-}$ mice.

\section{Acknowledgements}

We thank Keith Burling for assistance with plasma hormone and lipid measurements and members of the Endocrinology Unit, QMRI for helpful comments and discussions. The authors declare that there is no conflict of interest that would prejudice the impartiality of this scientific work.

\section{Funding}

This work has been supported by the Wellcome Trust Programme grant (J R S and K EC), by separate MRC Programme grants to S O'R and C J K and by the EU Sixth
Framework Programme Diabesity. Z $\mathrm{M}$ is supported by the Wellcome Trust PhD studentship, A P C by an MRC Clinician Scientist Award and N M M by the Wellcome Trust Research Career Development Fellowship.

\section{References}

Andrew R, Smith K, Jones GC \& Walker BR 2002 Distinguishing the activities of $11 \beta$-hydroxysteroid dehydrogenases in vivo using isotopically labeled cortisol. Journal of Clinical Endocrinology and Metabolism 87 277-285.

Buemann B, Vohl MC, Chagnon M, Chagnon YC, Gagnon J, Perusse L, Dionne F, Despres JP, Tremblay A, Nadeau A et al. 1997 Abdominal visceral fat is associated with a BclI restriction fragment length polymorphism at the glucocorticoid receptor gene locus. Obesity Research 5 186-192.

Bujalska IJ, Kumar S, Hewison M \& Stewart PM 1999 Differentiation of adipose stromal cells: the roles of glucocorticoids and $11 \beta$-hydroxysteroid dehydrogenase. Endocrinology 140 3188-3196.

Challis BG, Coll AP, Yeo GS, Pinnock SB, Dickson SL, Thresher RR, Dixon J, Zahn D, Rochford JJ, White A et al. 2004 Mice lacking proopiomelanocortin are sensitive to high-fat feeding but respond normally to the acute anorectic effects of peptide-YY3-36. PNAS 101 4695-4700.

Coll AP, Challis BG, Yeo GS, Snell K, Piper SJ, Halsall D, Thresher RR \& O'Rahilly S 2004 The effects of pro-opiomelanocortin deficiency on murine adrenal development and responsiveness to adrenocorticotropin. Endocrinology 145 4721-4727.

Coll AP, Challis BG, Lopez M, Piper S, Yeo GS \& O'Rahilly S 2005 Proopiomelanocortin-deficient mice are hypersensitive to the adverse metabolic effects of glucocorticoids. Diabetes 54 2269-2276.

Dallman MF, Strack AM, Akana SF, Bradbury MJ, Hanson ES, Scribner KA \& Smith M 1993 Feast and famine: critical role of glucocorticoids with insulin in daily energy flow. Frontiers in Neuroendocrinology 14 303-347.

Debons AF, Siclari E, Das KC \& Fuhr B 1982 Gold thioglucose-induced hypothalamic damage, hyperphagia, and obesity: dependence on the adrenal gland. Endocrinology 110 2024-2029.

Dobson MG, Redfern CP, Unwin N \& Weaver JU 2001 The N363S polymorphism of the glucocorticoid receptor: potential contribution to central obesity in men and lack of association with other risk factors for coronary heart disease and diabetes mellitus. Journal of Clinical Endocrinology and Metabolism 86 2270-2274.

Dong Y, Poellinger L, Gustafsson J-Å \& Okret S 1988 Regulation of glucocorticoid receptor expression: evidence for transcriptional and posttranslational mechanisms. Molecular Endocrinology 2 1256-1264.

Flier JS 2004 Obesity wars: molecular progress confronts an expanding epidemic. Cell 116 337-350.

Freedman MR, Horwitz BA \& Stern JS 1986 Effect of adrenalectomy and glucocorticoid replacement on development of obesity. American Journal of Physiology 250 R595-R607.

Fried SK, Russell CD, Grauso NL \& Brolin RE 1993 Lipoprotein lipase regulation by insulin and glucocorticoid in subcutaneous and omental adipose tissues of obese women and men. Journal of Clinical Investigation 92 2191-2198.

Geley S, Hartmann BL, Hala M, Strasser-Wozak EM, Kapelari K \& Kofler R 1996 Resistance to glucocorticoid-induced apoptosis in human T-cell acute lymphoblastic leukemia CEM-C1 cells is due to insufficient glucocorticoid receptor expression. Cancer Research 56 5033-5038.

Guyton AC 1991 Blood pressure control: special role of the kidneys and body fluids. Science 252 1813-1816.

Hammami MM \& Siiteri PK 1991 Regulation of 11ß-hydroxysteroid dehydrogenase activity in human skin fibroblasts: enzymatic modulation of glucocorticoid action. Journal of Clinical Endocrinology and Metabolism $\mathbf{7 3}$ 326-334.

Holmes MC, Yau JLW, French KL \& Seckl JR 1995 The effect of adrenalectomy on 5-hydroxytryptamine and corticosteroid receptor subtype messenger RNA expression in rat hippocampus. Neuroscience 64 $327-337$ 
Holmes MC, French KL \& Seckl JR 1997 Dysregulation of diurnal rhythms of serotonin 5-HT2C and corticosteroid receptor gene expression in the hippocampus with food restriction and glucocorticoids. Journal of Neuroscience 17 4056-4065.

Jamieson PM, Chapman KE, Edwards CRW \& Seckl JR 1995 11ßHydroxysteroid dehydrogenase is an exclusive $11 \beta$-reductase in primary cultures of rat hepatocytes: effect of physicochemical and hormonal manipulations. Endocrinology 136 4754-4761.

Jamieson PM, Walker BR, Chapman KE, Andrew R, Rossiter S \& Seckl JR $200011 \beta$-Hydroxysteroid dehydrogenase type 1 is a predominant $11 \beta-$ reductase in the intact perfused rat liver. Journal of Endocrinology 165 685-692.

Kalinyak JE, Dorin RI, Hoffman AR \& Perlman AJ 1987 Tissue-specific regulation of glucocorticoid receptor mRNA by dexamethasone. Journal of Biological Chemistry 262 10441-10444.

Kannisto K, Pietilainen KH, Ehrenborg E, Rissanen A, Kaprio J, Hamsten A \& Yki-Jarvinen H 2004 Overexpression of $11 \beta$-hydroxysteroid dehydrogenase-1 in adipose tissue is associated with acquired obesity andfeatures of insulin resistance: studies in young adult monozygotic twins. Journal of Clinical Endocrinology and Metabolism 89 4414-4421.

Kellendonk C, Eiden S, Kretz O, Schutz G, Schmidt I, Tronche F \& Simon E 2002 Inactivation of the GR in the nervous system affects energy accumulation. Endocrinology 143 2333-2340.

Kotelevtsev Y, Holmes MC, Burchell A, Houston PM, Schmoll D, Jamieson P, Best R, Brown R, Edwards CRW, Seckl JR et al. 1997 11ß-Hydroxysteroid dehydrogenase type 1 knockout mice show attenuated glucocorticoid inducible responses and resist hyperglycaemia on obesity or stress. PNAS 94 14924-14929.

Krude H, Biebermann H, Luck W, Horn R, Brabant G \& Gruters A 1998 Severe early-onset obesity, adrenal insufficiency and red hair pigmentation caused by POMC mutations in humans. Nature Genetics 19 155-157.

Lindsay RS, Wake DJ, Nair S, Bunt J, Livingstone DE, Permana PA, Tataranni PA \& Walker BR 2003 Subcutaneous adipose 11 $\beta$-hydroxysteroid dehydrogenase type 1 activity and messenger ribonucleic acid levels are associated with adiposity and insulinemia in Pima Indians and Caucasians. Journal of Clinical Endocrinology and Metabolism 88 2738-2744.

Livingstone DEW, Jones GC, Smith K, Jamieson PM, Andrew R, Kenyon CJ \& Walker BR 2000 Understanding the role of glucocorticoids in obesity: tissue-specific alterations of corticosterone metabolism in obese Zucker rats. Endocrinology 141 560-563.

Makimura H, Mizuno TM, Roberts J, Silverstein J, Beasley J \& Mobbs CV 2000 Adrenalectomy reverses obese phenotype and restores hypothalamic melanocortin tone in leptin-deficient ob/ob mice. Diabetes 49 1917-1923.

Masuzaki H, Paterson J, Shinyama H, Morton NM, Mullins JJ, Seckl JR \& Flier JS 2001 A transgenic model of visceral obesity and the metabolic syndrome. Science 294 2166-2170.

Masuzaki H, Yamamoto H, Kenyon CJ, Elmquist JK, Morton NM, Paterson JM, Shinyama H, Sharp MG, Fleming S, Mullins JJ et al. 2003 Transgenic amplification of glucocorticoid action in adipose tissue causes high blood pressure in mice. Journal of Clinical Investigation 112 83-90.

Morton NM, Holmes MC, Fiévet C, Staels B, Tailleux A, Mullins JJ \& Seckl JR 2001 Improved lipid and lipoprotein profile, hepatic insulin sensitivity, and glucose tolerance in $11 \beta$-hydroxysteroid dehydrogenase type 1 null mice. Journal of Biological Chemistry 276 41293-41300.

Morton NM, Paterson JM, Masuzaki H, Holmes MC, Staels B, Fievet C, Walker BR, Flier JS, Mullins JJ \& Seckl JR 2004 Novel adipose tissue mediated resistance to diet-induced visceral obesity in $11 \beta$-hydroxysteroid dehydrogenase type 1-deficient mice. Diabetes 53 931-938.

Morton NM, Densmore V, Wamil M, Ramage L, Nichol K, Bunger L, Seckl JR \& Kenyon CJ 2005 A polygenic model of the metabolic syndrome with reduced circulating and intra-adipose glucocorticoid action. Diabetes $\mathbf{5 4}$ 3371-3378.

Napolitano A, Voice MW, Edwards CRW, Seckl JR \& Chapman KE 1998 $11 \beta$-Hydroxysteroid dehydrogenase 1 in adipocytes: expression is differentiation-dependent and hormonally regulated. Journal of Steroid Biochemistry and Molecular Biology 64 251-260.
Nechushtan H, Benvenisty N, Brandeis R \& Reshef L 1987 Glucocorticoids control phosphoenolpyruvate carboxykinase gene expression in a tissue specific manner. Nucleic Acids Research 15 6405-6417.

Opherk C, Tronche F, Kellendonk C, Kohlmuller D, Schulze A, Schmid W \& Schutz G 2004 Inactivation of the glucocorticoid receptor in hepatocytes leads to fasting hypoglycemia and ameliorates hyperglycemia in streptozotocin-induced diabetes mellitus. Molecular Endocrinology 18 1346-1353.

Paterson JM, Morton NM, Fiévet C, Kenyon CJ, Holmes MC, Staels B, Seckl JR \& Mullins JJ 2004 Metabolic syndrome without obesity: hepatic overexpression of $11 \beta$-hydroxysteroid dehydrogenase type 1 in transgenic mice. PNAS 101 7088-7093.

Paulmyer-Lacroix O, Boullu S, Oliver C, Alessi MC \& Grino M 2002 Expression of the mRNA coding for $11 \beta$-hydroxysteroid dehydrogenase type 1 in adipose tissue from obese patients: an in situ hybridization study. Journal of Clinical Endocrinology and Metabolism 87 2701-2705.

Pilkis SJ \& Granner DK 1992 Molecular physiology of the regulation of hepatic gluconeogenesis and glycolysis. Annual Review of Physiology $\mathbf{5 4}$ 885-909.

Rascher W, Dietz R, Schomig A, Burkart G, Luth JB, Mann JF \& Weber J 1979 Modulation of sympathetic vascular tone by prostaglandins in corticosterone-induced hypertension in rats. Clinical Science 57 235s-237s.

Rask E, Olsson T, Söderberg S, Andrew R, Livingstone DE, Johnson O \& Walker BR 2001 Tissue-specific dysregulation of cortisol metabolism in human obesity. Journal of Clinical Endocrinology and Metabolism 86 $1418-1421$.

Reichardt HM, Umland T, Bauer A, Kretz O \& Schütz G 2000 Mice with an increased glucocorticoid receptor gene dosage show enhanced resistance to stress and endotoxic shock. Molecular and Cellular Biology 20 9009-9017.

Reshef L, Olswang Y, Cassuto H, Blum B, Croniger CM, Kalhan SC, Tilghman SM \& Hanson RW 2003 Glyceroneogenesis and the triglyceride/fatty acid cycle. Journal of Biological Chemistry 278 30413-31416.

Rosmond R, Chagnon YC, Holm G, Chagnon M, Pérusse L, Lindell K, Carlsson B, Bouchard C \& Björntorp P 2000 A glucocorticoid receptor gene marker is associated with abdominal obesity, leptin, and dysregulation of the hypothalamic-pituitary-adrenal axis. Obesity Research 8 211-218.

van Rossum EF, Koper JW, van den Beld AW, Uitterlinden AG, Arp P, Ester W, Janssen JA, Brinkmann AO, de Jong FH, Grobbee DE et al. 2003 Identification of the Bcll polymorphism in the glucocorticoid receptor gene: association with sensitivity to glucocorticoids in vivo and body mass index. Clinical Endocrinology 59 585-592.

Sainsbury A, Cusin I, Rohner-Jeanrenaud F \& Jeanrenaud B 1997 Adrenalectomy prevents the obesity syndrome produced by chronic central neuropeptide Y infusion in normal rats. Diabetes 46 209-214.

Saruta T 1996 Mechanism of glucocorticoid-induced hypertension. Hypertension Research 19 1-8.

Sasaki K, Cripe TP, Koch SR, Andreone TL, Petersen DD, Beale EG \& Granner DK 1984 Multihormonal regulation of phosphoenolpyruvate carboxykinase gene transcription. The dominant role of insulin. Journal of Biological Chemistry 259 15242-15251.

Sheppard KE, Roberts JL \& Blum M 1990 Differential regulation of type II corticosteroid receptor messenger ribonucleic acid expression in the rat anterior pituitary and hippocampus. Endocrinology 127 431-439.

Sowers JR 2004 Insulin resistance and hypertension. American Journal of Physiology. Heart and Circulatory Physiology 286 H1597-H1602.

Ukkola O, Pérusse L, Weisnagel SJ, Bergeron J, Després JP, Rao DC \& Bouchard C 2001a Interactions among the glucocorticoid receptor, lipoprotein lipase, and adrenergic receptor genes and plasma insulin and lipid levels in the Quebec Family Study. Metabolism 50 246-252.

Ukkola O, Rosmond R, Tremblay A \& Bouchard C 2001b Glucocorticoid receptor $\mathrm{Bcl} \mathrm{I}$ variant is associated with an increased atherogenic profile in response to long-term overfeeding. Atherosclerosis 157 221-224.

Vanderbilt JN, Miesfeld R, Maler BA \& Yamamoto KR 1987 Intracellular receptor concentration limits glucocorticoid-dependent enhancer activity. Molecular Endocrinology 1 68-74. 
Voice MW, Seckl JR, Edwards CRW \& Chapman KE 1996 11ßHydroxysteroid dehydrogenase type 1 expression in 2S-FAZA hepatoma cells is hormonally regulated; a model system for the study of hepatic glucocorticoid metabolism. Biochemical Journal 317 621-625.

Wallerath T, Godecke A, Molojavyi A, Li H, Schrader J \& Forstermann U 2004 Dexamethasone lacks effect on blood pressure in mice with a disrupted endothelial NO synthase gene. Nitric Oxide 10 36-41.

Whitworth JA, Schyvens CG, Zhang Y, Mangos GJ \& Kelly JJ 2001 Glucocorticoid-induced hypertension: from mouse to man. Clinical and Experimental Pharmacology and Physiology 28 993-996.
Yaswen L, Diehl N, Brennan MB \& Hochgeschwender U 1999 Obesity in the mouse model of pro-opiomelanocortin deficiency responds to peripheral melanocortin. Nature Medicine 5 1066-1070.

Received in final form 16 April 2007

Accepted 1 May 2007

Made available online as an Accepted Preprint

8 May 2007 